\title{
Seasonality and Correlations between Water Quality Parameters in the Lower Danube at Chiciu for the Period 2010-2012
}

\author{
RODICA-MIHAELA FRINCU ${ }^{1,2 *}$, CRISTIAN OMOCEA ${ }^{1,3}$, CERASELA-IULIANA ENI ${ }^{1,3}$, \\ ELEONORA-MIHAELA UNGUREANU', OLGA IULIAN ${ }^{1 *}$ \\ ${ }^{1}$ University Politehnica of Bucharest, Department of Inorganic Chemistry, Physical Chemistry and Electrochemistry, 313 \\ Splaiul Independentei, 060042, Bucharest, Romania \\ ${ }^{2}$ National Institute for Research \& Development in Chemistry and Petrochemistry - ICECHIM, 202 Splaiul Independentei, \\ 060021, Bucharest, Romania \\ ${ }^{3}$ Water Basin Administration Dobrogea - Litoral, 127 Mircea cel Batran Blvd., 900592, Constanta, Romania
}

\begin{abstract}
The Danube River receives tributaries with different pollution loads, according to the social-economic characteristics of the adjacent regions. Water quality monitoring data from Chiciu, Calarasi county, Romania, for the three-year period (2010-2012), were analysed using statistical methods in order to identify correlations between parameters, as well as their evolution during the study period. The analysis has confirmedpositive correlations between nitrates and total nitrogen and between ortho-phosphates and total phosphorus. Negative correlations were found between water temperatures on one side and dissolved oxygen and nitrates on the other side. These parameters have a seasonal evolution, with high temperatures and low dissolved oxygen and nitrates levels during summer periods. Linear regression highlights decreasing nutrients pollution during the study period, which may be due to improved wastewater treatment along Danube tributaries.
\end{abstract}

Keywords: Danube river, Chiciu monitoring station, water pollution, nutrients, dissolved oxygen

The Danube river drains waters from the territories of 19 European countries, including $97.4 \%$ of the territory of Romania, which is located in the Lower Danube, from $\mathrm{km} 0$ to $\mathrm{km} \mathrm{1075and} \mathrm{is} \mathrm{sharing} \mathrm{borders} \mathrm{with} \mathrm{Serbia,} \mathrm{Bulgaria,}$ Moldavia and Ukraine. Between Bazias, where it enters Romania, and the Danube Delta, where it flows into the Black Sea, at Chiciuvillage in Calarasi county the Danube leaves the border with Bulgaria and flows entirely through Romanian territory until Giurgiulești, Galati county, at the border with the Republic of Moldova.

The Danube is subject to multiple anthropogenic pressures, which affect its water quality and its flow. Sources of pollution include industrial and municipal wastewater, fertilizers run-off from agricultural land, alterations of riverbed. The Danube basin includes an important number of heavily modified water bodies. The morphology of the river has been altered by human interventions [1], an example being the hydropower works at Iron Gates (Portile de Fier)on the Romanian - Serbian border, which had a significant impact on sediment discharge in the Lower Danube [2,3].Several studies have been carried out in order to assess the impact of environmental factors and human activities on Danube water pollution[4-6].

A study carried out by Diamantini et al. [7] for three river basins in Europe found that some of the main factors that influence water quality parameters are air temperature, flow, population and land use. A wide study on sediments sampled during the Second Joint Danube Survey, in 2007 all along the Danube, identified as main possible anthropogenic sources of pollution wastewater discharge, mining and agriculture [8].

The water quality of the Danube River is closely monitored by riparian countries coordinated by the International Commission for the Protection of the Danube River (ICPDR), in line with the EU Water Framework Directive [9], and management plans are implemented in order to reduce pollution and reach good status.

During the period 2010-2012, in Romania some additional factors that could contribute to changes in water quality were the upgrading of wastewater treatment plants in municipalities discharging to Arges river, a Danube tributary. In addition, Chiciu village area was closely monitored during the period 2011-2014 within the ROMOMED Project (Monitoring of Environmental Impact of the Works for Improvement of the Navigation Conditions on the Danube between Calarasi and Braila, km 375 - km 175) [10-12].

In this paper, a set of water quality monitoring data for the three years (2010-2012) at Chiciu village, Calarași county is analysed in order to identify the main parameters that describe the variation of the dataset and correlations between different parameters. The evolution in time of key parameters like total nitrogen may provide to authorities useful information regarding the efficiency of measures taken to reduce pollution. Water samples were taken from the Danube river at Chiciu monitoring station, at about $60 \mathrm{~km}$ downstream from the confluence between the Danube and the Argeș river. The Arges river collects insufficiently treated municipal sewerage waters from Bucharest, the capital city of Romania, inhabited by 2.1 million people, and discharges them into the Danube, so their impact on water quality should be investigated. To the best of our knowledge, this issue has not yet been addressed.

\footnotetext{
*email: icechim.calarasi@gmail.com; olgaiulian@yahoo.com
} 
Moreover, this work is the first of a series of studies on Danube water quality in the years following the period under consideration. This study serves as a reference base to assess the impact of the second phase of upgrading works at the Bucharest Wastewater Treatment Plant (2017-2019) towards improving Danube water quality downstream.

The parameters included in this study are some of the most relevant for assessing water quality, namely water temperature, dissolved oxygen, 5 days biochemical oxygen demand, ammonium nitrogen, nitrite nitrogen, nitrate nitrogen, total nitrogen, ortho-phosphates and total phosphorus. All the data were analysed using statistical methods.

\section{Experimental part}

Water sampling and analysis

Chiciu monitoring station is located, in the Lower Danube at $375 \mathrm{~km}$ (geographical coordinates: latitude $44^{\circ} 07^{\prime} 60.0^{\prime \prime} \mathrm{N}$ and longitude $27^{\circ} 16^{\prime} 22.0^{\prime \prime} \mathrm{E}$ ). A number 234 water samples, collected from both banks of the river and from the middle during January 2010 - December 2012, were analysed within the national monitoring programme. Sampling was carried out according to standard EN ISO 5667:2007 (parts 1, 3, 4, 6, 10,11) and internal specific procedures of National Administration "Romanian Waters" (ANAR). The measurements and analysis methods are presented in Table 1.

Table 1

ANALYSED PARAMETERS OF WATER AND METHODS

\begin{tabular}{|c|c|c|c|}
\hline Parameter & Abbreviation & Unit & Method and standards \\
\hline Water Temperature & WT & ${ }^{\circ} \mathrm{C}$ & \\
\hline Dissolved oxygen & $\mathrm{DO}$ & $\mathrm{mgO}_{2} / \mathrm{L}$ & $\begin{array}{c}\text { Water quality - Determination of dissolved oxygen - } \\
\text { Electrochemical probe method } \\
\text { SR EN 25814:1999 }\end{array}$ \\
\hline $\begin{array}{l}\text { Biochemical oxygen } \\
\text { demand ( } 5 \text { days) }\end{array}$ & BOD5 & $\mathrm{mgO}_{2} / \mathrm{L}$ & $\begin{array}{c}\text { Water quality - Determination of biochemical oxygen } \\
\text { demand after n days - Part 2: Method for undiluted } \\
\text { samples (modified ISO 5815:1989), SR EN 1899-2:2002 }\end{array}$ \\
\hline Ammonium nitrogen & $\mathrm{N}-\mathrm{NH}_{4}$ & $\mathrm{mg} / \mathrm{L}$ & $\begin{array}{l}\text { Water quality -Determination of ammonium - Part 1: } \\
\text { Manual spectrometric method ISO 7150-1:2001 }\end{array}$ \\
\hline Nitrite nitrogen & $\mathrm{N}-\mathrm{NO}_{2}$ & $\mathrm{mg} / \mathrm{L}$ & $\begin{array}{l}\text { Determination of nitrite - Molecular absorption } \\
\text { spectrometric method SR EN 26777:2002 }\end{array}$ \\
\hline Nitrate nitrogen & $\mathrm{N}-\mathrm{NO}_{3}$ & $\mathrm{mg} / \mathrm{L}$ & $\begin{array}{l}\text { Water quality -Determination of nitrate -Part 3: } \\
\text { Spectrometric method using sulfosalicylic acid ISO } \\
7890-3: 2000\end{array}$ \\
\hline Total nitrogen & $\mathrm{TN}$ & $\mathrm{mg} / \mathrm{L}$ & $\begin{array}{c}\text { Water Quality. Nitrogen Determination. } \\
\text { Determination of total bound nitrogen }(\mathrm{TNb}) \text { after } \\
\text { oxidation SR EN 12260:2004 }\end{array}$ \\
\hline Ortho-phosphates & $\mathrm{P}-\mathrm{PO}_{4}$ & $\mathrm{mg} / \mathrm{L}$ & $\begin{array}{c}\text { Water quality -Determination of phosphorus - } \\
\text { Ammonium molybdate spectrometric method EN ISO } \\
6878: 2005\end{array}$ \\
\hline Total Phosphorus & $\mathrm{TP}$ & $\mathrm{mg} / \mathrm{L}$ & $\begin{array}{c}\text { Water quality -Determination of phosphorus - } \\
\text { Ammonium molybdate spectrometric method EN ISO } \\
6878: 2005\end{array}$ \\
\hline
\end{tabular}

\section{Statistical analysis methods}

Environmental data were analysed using statistical methods in order to assess the quality of environmental factors against given standards, to identify correlations between different parameters and to see how the parameters have evolved in time, particularly if some changes have occurred in a certain region. The statistical methods used in this study are summary statistics, correlation (Pearson and Spearman) analysis, covariance, principal component analysis and linear regression.

Principal component analysis (PCA) was used for the large experimental dataset with many parameters in order to identify which parameters play the most important role in its variation. This analysis may also be used to validate the results of the correlation analysis. By centring and scaling data, the influence of measuring units and orders of magnitude is removed. Linear regression was also applied as a modelling method that presumes a linear dependence between two variables and it was used to analyse the evolution in time of studied parameters.

Statistical analyses were carried out using the RStudio software Version 1.1.463, based on R version 3.5.2.

\section{Results and discussions \\ Summary statistics}

The monitoring data set was checked for consistency, and the parameters with the highest number of observations were selected for further analysis. Data are presented in a statistical Table (Table 2) which includes the maximum and minimum values, mean, median, $1^{\text {st }}$ quartile (the middle value between minimum and median) and $3^{\text {rd }}$ quartile (the middle value between medium and maximum value). 
Table 2

DESCRIPTIVE STATISTICS OF THE ANALYSED DATA SET

\begin{tabular}{|c|c|c|c|c|c|c|}
\hline \multirow[t]{2}{*}{ Parameter } & \multicolumn{6}{|c|}{ Value } \\
\hline & Minimum & $\begin{array}{c}\text { 1st } \\
\text { quartile }\end{array}$ & Median & Mean & $\begin{array}{c}\text { 3rd } \\
\text { quartile }\end{array}$ & Maximum \\
\hline Water Temperature, $\mathrm{WT}\left[{ }^{\circ} \mathrm{C}\right]$ & 0.50 & 6.50 & 13.00 & 13.68 & 21.00 & 29.50 \\
\hline Dissolved Oxygen, DO $\left[\mathrm{mgO}_{2} / \mathrm{L}\right]$ & 6.160 & 8.130 & 9.020 & 9.188 & 10.170 & 12.960 \\
\hline $\begin{array}{l}\text { Biochemical Oxygen Demand (5 } \\
\text { days), BOD5 }\left[\mathrm{mgO}_{2} / \mathrm{L}\right]\end{array}$ & 0.459 & 1.230 & 1.710 & 2.077 & 2.180 & 71.760 \\
\hline $\begin{array}{l}\text { Ammonium Nitrogen, } \mathrm{N}^{-\mathrm{NH}_{4}} \\
{[\mathrm{mg} / \mathrm{L}]}\end{array}$ & 0.0115 & 0.0500 & 0.1120 & 0.1403 & 0.2130 & 0.4980 \\
\hline Nitrite Nitrogen, $\mathrm{N}^{-\mathrm{NO}_{2}}[\mathrm{mg} / \mathrm{L}]$ & 0.0025 & 0.0130 & 0.0200 & 0.0207 & 0.0250 & 0.0720 \\
\hline Nitrate Nitrogen, $\mathrm{N}_{-} \mathrm{NO}_{3}[\mathrm{mg} / \mathrm{L}]$ & 0.610 & 1.350 & 1.680 & 1.701 & 2.060 & 4.041 \\
\hline Total Nitrogen, TN [mg/L] & 0.886 & 1.750 & 2.100 & 2.165 & 2.651 & 4.900 \\
\hline Ortho-phosphates, $\mathrm{P}_{-} \mathrm{PO}_{4}[\mathrm{mg} / \mathrm{L}]$ & 0.0045 & 0.0250 & 0.0430 & 0.0489 & 0.0650 & 0.1330 \\
\hline Total Phosphorus, TP [mg/L] & 0.0110 & 0.0500 & 0.0700 & 0.0748 & 0.1010 & 0.2500 \\
\hline
\end{tabular}

Table 2 allows us to assess the water quality during the study period according to norms. In Romania water quality assessment is regulated by Ministry Order 161/2006 regarding classification of surface waters [13]. The Order defines five quality classes I-V, with class I being best quality and class V the poorest. According to the limits set in this Order, values of measured DO range between class III (minimum value) and class I (maximum value). The median is also in class I ( $>9 \mathrm{mg} / \mathrm{L}$, which means that more than $50 \%$ of measured values are in class I.

BOD5 values up to the $3^{\text {rd }}$ quartile are in class I, which means that more than $75 \%$ of measured values are below the $3 \mathrm{mg} \mathrm{O} / 2$ limit. There is one extreme outlier, the maximum value, but all the other values are smaller than $5 \mathrm{mg} \mathrm{O}_{2} / \mathrm{L}$, which is the class II limit.

Ammonium levels are also in class I, with most values lower than $0.4 \mathrm{mg} \mathrm{N} / \mathrm{L}$. Only 4 values are in class II, including the maximum value. Nitrites qualify in classes I to IV. The first quartile in already in class II, being higher than 0.01 $\mathrm{mg} \mathrm{N} / \mathrm{L}$, and the third quartile is also in class II $(<0.03 \mathrm{mg} \mathrm{N} / \mathrm{L})$. The maximum value is in class IV. Nitrates values are in classes I-III, with the $1^{\text {st }}$ and $3^{\text {rd }}$ quartiles in class II, while the maximum value is in class III. Total Nitrogen values are in classes I and II. From the $1^{\text {st }}$ quartile to the maximum, all values are in class II (between $1.5-7 \mathrm{mg} \mathrm{N} / \mathrm{L}$ ). It should also be noted that all values for nitrates are much lower than the EU Water Framework Directive limit of $50 \mathrm{mg} / \mathrm{L}$. Ortho-phosphates are in class I up to the $3^{\text {rd }}$ quartile, while the maximum value is in class II. Total Phosphorus is also in class I up to the $3^{\text {rd }}$ quartile, with the maximum value in class II.

According to Romanian Standards, most values of the analysed parameters from period 2010-2012 in Chiciu are in water quality classes I and II.

\section{Correlation and Covariance Analysis}

Correlation and covariance analysis were carried out by calculating Pearson and Spearman coefficients. Figure 1 represents the nine selected variables plotted against each other below the diagonal, with Pearson correlation coefficients above the diagonal and histograms on the diagonal. Histograms show if data are skewed and it can be noticed that BOD, as well as ammonium, nitrates, nitrates and phosphorus data are skewed to the left, which may be an indication of accidental pollution.

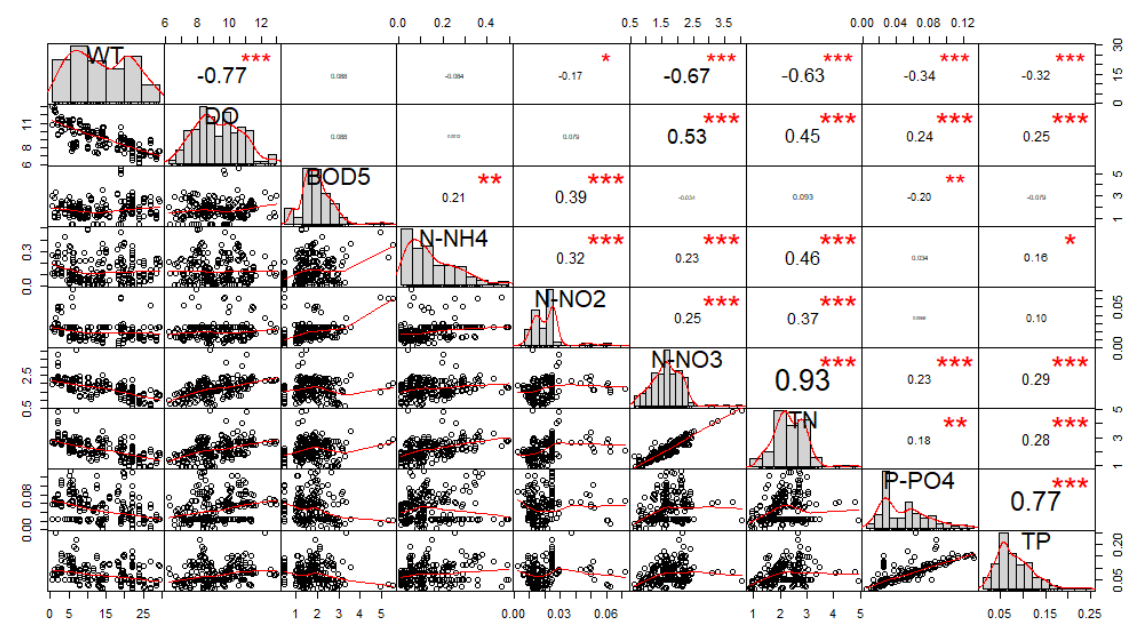

Fig. 1. Pairwise scatterplot matrix for the selected parameters with Pearson correlation factors for each pair. Significance codes for p values: $0.01<\mathrm{p}<0.05(*), 0.001<\mathrm{p}<0.01(* *), 0<\mathrm{p}<0.001(* * *)$. To improve the accuracy of the analysis, one BOD5 outlier was removed 
Spearman's rank correlation coefficients are a non-parametric measure of monotonic associations between variables and were calculated in addition to Pearson's correlation because many of the analysed data are skewed and include outliers. Significant positive (a relationship in which both variables move in tandem - that is, in the same direction) linear correlations are noticed between nitrate nitrogen $\mathrm{N}^{-\mathrm{NO}_{3}}$ and total nitrogen $\mathrm{TN}$ (0.93 Pearson, 0.89 Spearman). Also, significant positive correlations are between ortho-phosphates $\mathrm{P}_{-} \mathrm{PO}_{4}$ and total phosphorus TP (0.77 Pearson, 0.81 Spearman) while a significant negative correlation is noticed between water temperature WT and dissolved oxygen DO (-0.77 Pearson, -0.77 Spearman). There are also weaker negative correlations between $\mathrm{WT}$ and $\mathrm{N}-\mathrm{NO}_{3}(-0.67$ Pearson, -0.70 Spearman) and between WT and TN (-0.63 Pearson, -0.65 Spearman). These results are supported by the low calculated $\mathrm{p}$ values $(\mathrm{p}<0.001)$.The negative correlations between water temperature, on one side, and $\mathrm{DO}, \mathrm{N}-\mathrm{NO}_{3}, \mathrm{TN}$ on the other side may be a reflection of eutrophication during the warm seasons, solar radiation and the availability of nutrients leading to a proliferation of algae, which consume nitrogen and phosphorus for their metabolism, while their decay depletes the waters of dissolved oxygen.

The negative correlation between WT and DO is easily explained by the physical solubility of oxygen in water, which decreases as temperatures rise (Henry's law). However, the seasonal variation of nutrients concentrations (nitrogen and phosphorus) would require further investigation of the factors that influence the values of these parameters (population density, livestock numbers, land use, agriculture activities, physical and metabolic processes).

\section{Principal component analysis}

Principal component analysis (PCA) was carried out in order to identify which parameters have a stronger influence on the variation of the data set and relationships between them. Because the selected variables have different units of measure and ranges of variation, data were scaled and centred (normalised) before calculating the principal components. The standard deviation of each of the principal components (PC), and their rotations (or loadings) are presented in Table 3 . Loadings are the coefficients of the linear combinations of the continuous variables [14]. The new variables (PC1, PC2, PC3 etc.) are factors or components.

Table 3

RESULTS OF PCA FOR CHICIU DATA SET (2010-2012)

\begin{tabular}{|c|c|c|c|c|c|c|c|c|c|}
\hline PCA & PC1 & PC2 & PC3 & PC4 & PC5 & PC6 & PC7 & PC8 & PC9 \\
\hline $\begin{array}{c}\text { Water Temperature, } \\
\text { WT }\left[{ }^{\circ} \mathrm{C}\right]\end{array}$ & 0.4460 & -0.0374 & -0.3318 & 0.0410 & 0.0960 & -0.2286 & 0.4315 & -0.6609 & -0.0581 \\
\hline $\begin{array}{l}\text { Dissolved Oxygen, } \\
\mathrm{DO}\left[\mathrm{mgO}_{2} / \mathrm{L}\right.\end{array}$ & -0.3775 & 0.0711 & 0.4524 & -0.0584 & -0.1375 & 0.5356 & 0.3507 & -0.4607 & -0.0577 \\
\hline $\begin{array}{c}\text { Biochemical Oxygen } \\
\text { Demand }(5 \text { days }), \\
\text { BOD5 }\left[\mathrm{mgO}_{2} / \mathrm{L}\right]\end{array}$ & -0.0519 & -0.2890 & 0.0442 & -0.9398 & 0.0435 & -0.1597 & 0.0076 & -0.0331 & 0.0066 \\
\hline 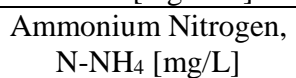 & -0.1920 & -0.3454 & -0.5459 & 0.0215 & 0.4613 & 0.5436 & -0.0801 & -0.0232 & 0.1735 \\
\hline $\begin{array}{l}\text { Nitrite Nitrogen, N- } \\
\mathrm{NO}_{2}[\mathrm{mg} / \mathrm{L}]\end{array}$ & -0.1944 & -0 & -0.3854 & 0 & 7 & 0.0 & 71 & .0502 & 0.0475 \\
\hline $\begin{array}{l}\text { Nitrate Nitrogen, } \mathrm{N}- \\
\mathrm{NO}_{3}[\mathrm{mg} / \mathrm{L}]\end{array}$ & -0.4620 & -0.1465 & 0.1286 & 0.1775 & 0.1689 & -0.4811 & 0.0749 & -0.1742 & 0.6489 \\
\hline $\begin{array}{c}\text { Total Nitrogen, TN } \\
{[\mathrm{mg} / \mathrm{L}]}\end{array}$ & -0.4640 & -0.2609 & -0.0407 & 0.1648 & 0.2100 & -0.3202 & 0.0196 & -0.0491 & -0.7338 \\
\hline $\begin{array}{c}\text { Ortho-phosphates, P- } \\
\mathrm{PO}_{4}[\mathrm{mg} / \mathrm{L}]\end{array}$ & -0.2582 & 0.5815 & -0.2771 & -0.1596 & -0.0321 & -0.0548 & -0.5555 & -0.4232 & -0.0357 \\
\hline $\begin{array}{c}\text { Total Phosphorus, TP } \\
{[\mathrm{mg} / \mathrm{L}]}\end{array}$ & -0.2929 & 0.4918 & -0.3765 & -0.1520 & -0.0087 & -0.0536 & 0.6078 & 0.3673 & 0.0097 \\
\hline Standard deviation & 1.8779 & 1.2600 & 1.1208 & 0.9757 & 0.8411 & 0.7187 & 0.4874 & 0.4240 & 0.1942 \\
\hline Proportion of Variance & 0.3918 & 0.1763 & 0.1396 & 0.1058 & 0.0786 & 0.0574 & 0.0264 & 0.0200 & 0.0042 \\
\hline Cumulative Proportion & 0.3918 & 0.5681 & 0.7077 & 0.8134 & 0.8921 & 0.9494 & 0.9758 & 0.9958 & 1.0000 \\
\hline
\end{tabular}

For example, the loadings of PC1 mean that it is mainly influenced by TN $(-0.46), \mathrm{N}^{-N_{3}}(-0.46)$, WT $(0.45)$ and DO (-0.38), and the proportion of variance means that PC1 explains $39.18 \%$ of the variance of the data set. The most important roles in PC2 are played by ortho-phosphates $\mathrm{P}^{-\mathrm{PO}_{4}}(0.58)$ and TP $(0.49)$, followed by nitrites $\mathrm{N}-\mathrm{NO}_{2}(0.35)$ and ammonium nitrogen $\mathrm{N}^{-\mathrm{NH}_{4}}(0.35)$. Together, PC1 and PC2 explain $56.81 \%$ of the variation of the data set. PC1 (Dim1) and PC2 (Dim2) are represented in Figure2. 


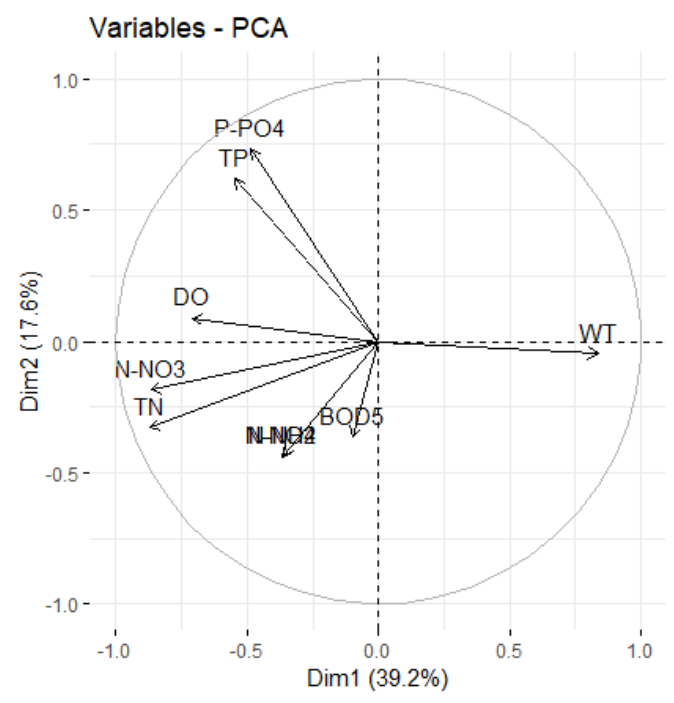

Fig. 2. Graphical representation of Principal Component Analysis, PC1 (Dim1) and PC2 (Dim2) of working data set (Chiciu 2010-2012)

The arrows in Figure 2 represent variables, and the longer the arrow, the higher the variable's influence on the data set. The angles between arrows represent correlations between parameters: right angles indicate no correlation, angles less than 90 degrees indicate positive correlation and angles more than 90 degrees indicate increasing negative correlation. The Figure indicates very clearly the strong negative correlation between water temperature WT and dissolved oxygen DO that was identified in the previous section, as well as the positive correlations between $\mathrm{N}-\mathrm{NO}_{3}$ and TN on one side and $\mathrm{P}_{-} \mathrm{PO}_{4}$ and TP on the other side.

The most important roles play the parameters WT, DO, N-NO 3 and TN in PC1, $\mathrm{P}_{-} \mathrm{PO}_{4}$ and TP in PC2, N-NH4in PC3, BOD5 in PC4, and N-NO 2 in PC5, respectively. Together, the first five components explain $89.21 \%$ of the variation of the dataset.

\section{Graphical Data Representation and Linear Regression}

In this section, the groups of parameters that were identified as correlated are represented in scatterplots according to sampling dates, in order to investigate how they evolved during the study period 2010-2012 (Figures 3-6). To make the charts clearer, only data from the Romanian left bank were represented.

Figure 3 represents the water temperature (WT), dissolved oxygen (DO) and total nitrogen (TN), the variables for which a high correlation was identified. The Figure highlights the seasonal variation, but there is no obvious general trend during the three years when data were collected. It can be noticed that high WT values correspond to low DO and $\mathrm{TN}$, in agreement with the negative correlations highlighted before.

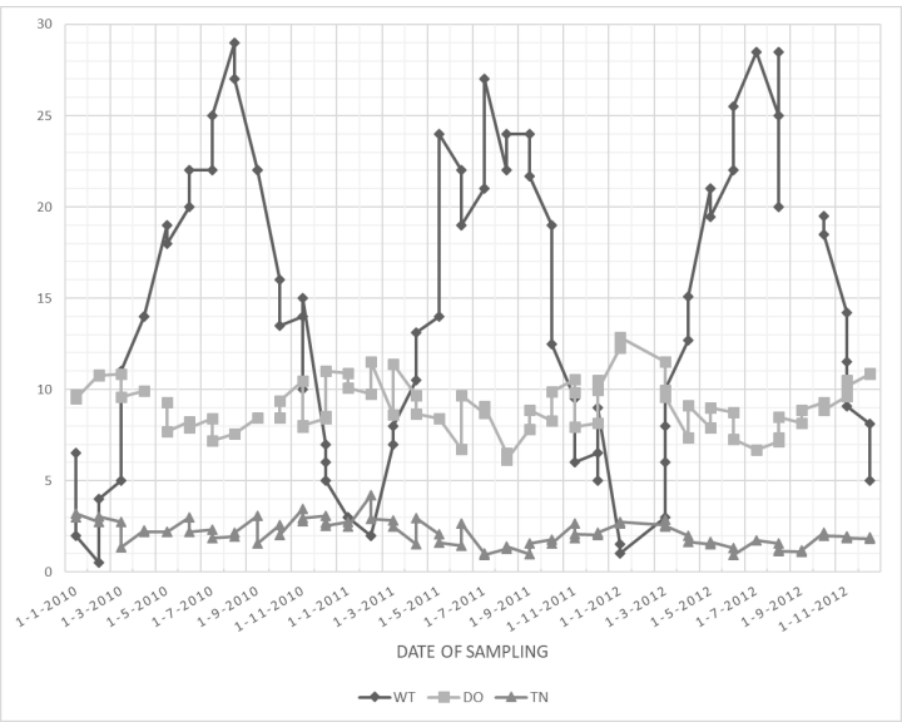

Fig. 3. Graphical representation of water temperature WT $\left[{ }^{\circ} \mathrm{C}\right]$, dissolved oxygen

$\mathrm{DO}[\mathrm{mg} / \mathrm{L}]$ and total nitrogen

TN [mg/L] at Chiciu, left bank, 2010-2012

The values of the different nitrogen species $\left(\mathrm{N}_{-} \mathrm{NH}_{4}, \mathrm{~N}-\mathrm{NO}_{2}, \mathrm{~N}-\mathrm{NO}_{3}\right)$ are represented in Figure 4 together with total nitrogen (TN). Values for nitrates and TN are close, showing that nitrates are the most abundant nitrogen species. The chart also shows seasonal variations, with lower values during summer and higher values in the cold season, as well as the positive correlation between $\mathrm{N}-\mathrm{NO}_{3}$ and $\mathrm{TN}$ identified before. Ammonium nitrogen $\left(\mathrm{N}-\mathrm{NH}_{4}\right)$ could be an indicator for sewerage pollution, as it is rapidly released from urea. However, its variation does not present an obvious pattern. 
The regression line indicates a slight decrease in TN values during the study period ( $p$-value $<0.001$ ), which may be a consequence of improved wastewater treatment in Bucharest (first phase of secondary treatment commissioned in the end of 2011).

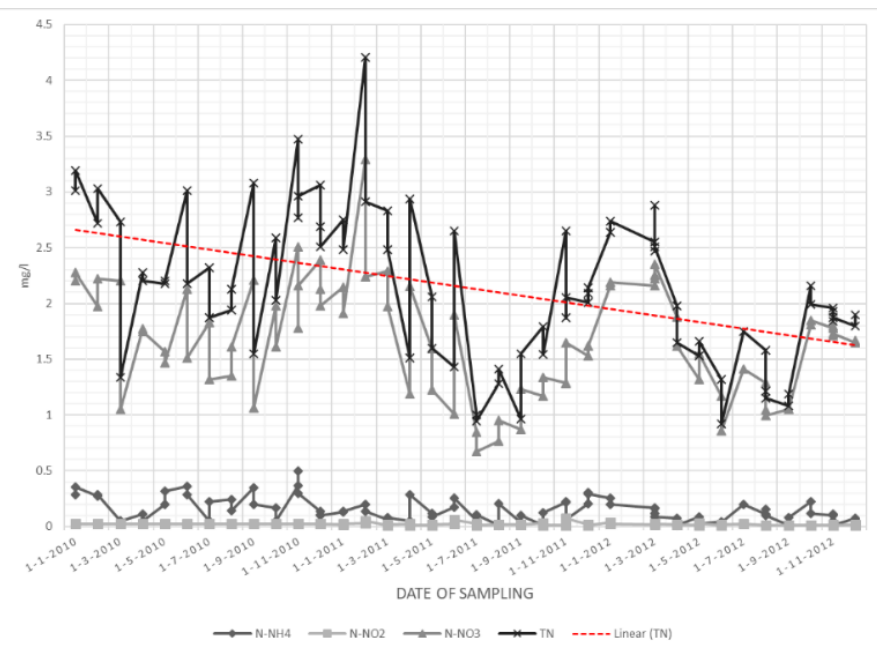

Fig. 4. Graphical representation of N$\mathrm{NH}_{4}[\mathrm{mg} / \mathrm{L}], \mathrm{N}-\mathrm{NO} 2[\mathrm{mg} / \mathrm{L}], \mathrm{N}-\mathrm{NO} 3$ $[\mathrm{mg} / \mathrm{L}]$ and total nitrogen $\mathrm{TN}[\mathrm{mg} / \mathrm{L}]$ at Chiciu monitoring station, left bank, 2010-2012.Dotted regression line is for TN

Figure 5 represents the phosphorus parameters $\mathrm{P}_{-} \mathrm{PO}_{4}$ and TP. The represented values are close, so it can be seen that ortho-phosphates are the main contributors to total phosphorus. The seasonal variation is more obvious in 2011 and 2012 and the linear regression line for TP also indicates a slight decline of pollution during the analysed period ( $\mathrm{p}$-value: 0.006319). Ortho-phosphates are the main phosphorus species, and their levels are close to zero in some of the summer months, so they appear to be the limiting factor for algal growth in this case, like in most surface waters [15].

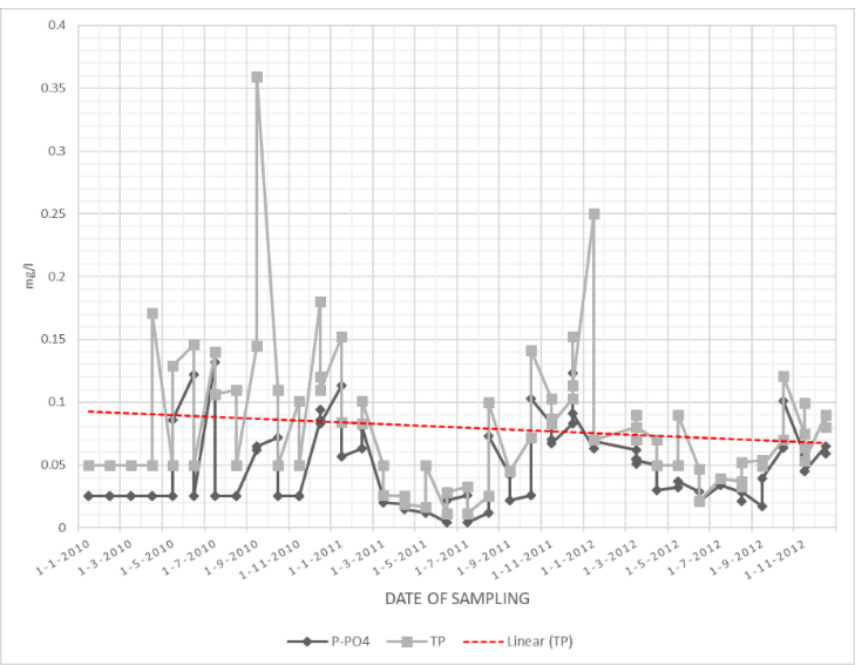

Fig. 5. Graphical representation of $\mathrm{P}_{-} \mathrm{PO}_{4}[\mathrm{mg} / \mathrm{L}]$ and total phosphorus TP [mg/L] at Chiciu monitoring station, left bank, 2010-2012.Dotted regression line is for $\mathrm{TP}$

The minimum level of nutrients reached during hot and dry periods is probably due both to reduced inputs from agricultural land runoff and increased biological activity in the water body. In addition to biological uptake, at low oxygen levels nitrogen is removed from surface waters by denitrification, a process in which different oxidation forms are reduced to molecular $\mathrm{N}_{2}$ and released to the atmosphere. In this respect, it was estimated that in Northwest Europe about half of the nitrogen released to surface waters is lost by denitrification until they reach the sea [16]. A Joint Research Centre project has successfully modelled nitrates variations in the Danube using the Soil and Water Assessment Tool (SWAT), however for the denitrification process it was not possible to generate an accurate model [6].

Oxygen parameters are used to monitor organic pollution in water and are presented in Figure 6. Chemical Oxygen Demand (COD) was not included in the analysed data set because COD-Cr values are not relevant for 2010, and both COD-Cr and COD-Mn were less frequently determined than BOD5.

Biochemical Oxygen Demand (BOD5) is the amount of oxygen needed for decomposition of organic matter by microorganisms (bacteria) in five days and is measured in $\mathrm{mg} / \mathrm{L}$. The linear regression for BOD5 (Figure 6) also shows a slight decline during the study period ( $\mathrm{p}$-value $<0.001$ ). Determination of Chemical Oxygen Demand (COD) is also a method to estimate organic loads in water. COD-Mn is carried out using $\mathrm{KMnO}_{4}$ in $\mathrm{H}_{2} \mathrm{SO}_{4}$ and has similar values to BOD.This method oxidizes biodegradable organic matter and around 30-40\% of the non-biodegradable compounds. COD-Cr uses $\mathrm{K}_{2} \mathrm{Cr}_{2} \mathrm{O}_{7}$ as oxidising agent in acid environment and it determines 60 - 70\% of organic matter [17]. 


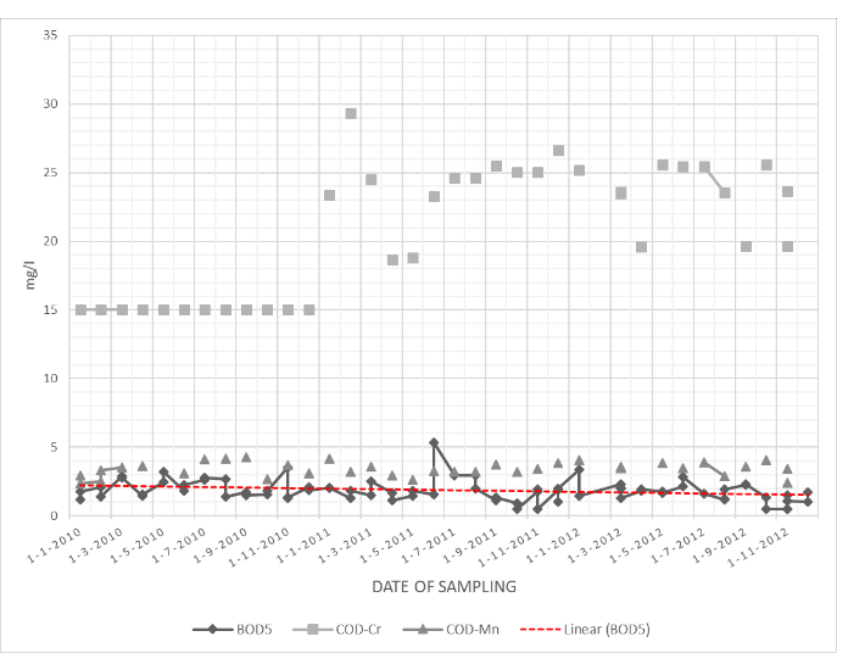

Fig. 6.Graphical representation of chemical oxygen demand (COD-Cr, COD-Mn) [mg/L] and biochemical oxygen demand BOD5 $[\mathrm{mg} / \mathrm{L}]$ at Chiciu monitoring station, left bank, 2010-2012. Dotted regression line is for BOD5

Potassium dichromate is a stronger oxidising agent than potassium permanganate, which is why COD-Cr values are higher than COD-Mn values [18].

The difference between COD-Cr on one side and COD-Mn and BOD5 on the other side, which can be seen in Figure 6 , may be an indication that a large part of the organic pollutants present in Danube water are complex compounds, which are not easily biodegradable.

\section{Conclusions}

The Danube water monitoring data from Chiciu monitoring station for the period 2010-2012 show seasonal variations and correlations between parameters like water temperature, dissolved oxygen, nitrates and total nitrogen. Nutrients pollution loads appear to have a declining trend, which may be related to improved wastewater treatment in large cities discharging into Danube tributaries.

The analysed data indicate a possible run-off from agricultural land as main nitrogen pollution source, although the low nitrogen levels during summer periods may be also a result of intensification of algal growth, who use nutrients for their metabolism. Phosphorus appears to be the limiting factor for algae proliferation, because its concentration in the study area is close to zero in some of the summer months.

\section{References}

1.GRECU, F., GRIGORE, S., TOROIMAC, G., GHITA, C., Proceedings of the Romanian Geomorphology Symposium, 33rd edition, Iași, 2017, p.56.

2.MATIC BUJAGIC, I., GRUJIC, S., LAUSEVIC, M., HOFMANN, T., MICIC, V., Sci. Total Environ, 662, 2019, p. 77.

3.GOGOASE NISTORAN, D., IONESCU, C., PATRU, G., ARMAS, I., GRIGORIE OMRANI, S., Energy Procedia, 112,2017, p. 67.

4.CORDIS EU Research Results. Available online: https://cordis.europa.eu/project/rcn/54443/factsheet/en.

5.KROISS, H., ZESSNER M., LAMPERT, C., Chem. Ecol., 22, no. 5, 2006,p. 347.

6.MALAGÓ, A., BOURAOUI, F., VIGIAK, O., GRIZZETTI B., PASTORI, M., Sci. Total Environ., 603-604, 2017 , p. 196.

7.DIAMANTINI, E., LUTZ, S.R., MALLUCCI, S., MAJONE, B., MERZ, R., BELLIN, A., Sci. Total Environ., 612,2018, p. 49.

8.COMERO, S., VACCARO, S., LOCORO, G., DE CAPITANI L., GAWLIK, B., Chemosphere, 95,2014, p. 329.

9.***EUR-Lex. Available online: https://eur-lex.europa.eu/Legal-content/EN/TXT/?uri=CELEX:32000L0060

10.IONESCU, P., RADU, V.M., DEAK, G., IVANOV, A.A., DIACU, E.,Rev. Chim., 66, no.8, 2015, p. 1088.

11.RADU, V.M., IVANOV, A.A., IONESCU, P., DEÁK G., DIACU, E, Rev. Chim., 67, no.3, 2016, p. 391.

12.RADU, V.M., DIACU, E., IONESCU, P., DEÁK G., Rev. Chim., 66, no.5,2015, p. 601.

13.NATIONAL ADMINISTRATION "ROMANIAN WATERS" (ANAR), available online: http://www.rowater.ro/dacrisuri/ Documente\% 20Repository/Legislatie/gospodarirea\%20apelor/ORD.\%20161_16.02.2006.pdf

14.Computing and visualizing PCA in R. Available online: https://tgmstat.wordpress.com/2013/11/28/computing-and-visualizing-pca-in-r/ 15.ANDERSON, D., GLIBERT, P., BURKHOLDER, J., Estuaries, 25, 2002, p. 704.

16.ANDREWS, J., BRIMBLECOMBE, P., JICKELLS, T., LISS P., REID, B., An Introduction to Environmental Chemistry, $2^{\text {nd }}$ edition, Blackwell Publishing, 2004, p. 168.

17.IOJĂ, I.C., Metode de cercetare ssi evaluare a starii mediului, Editura Etnologica, Bucuresti, 2013, p.69.

18.SAWYER, C.N., MCCARTY, P.L., PARKIN. G.F., Chemistry for environmental engineering and science, 5th edition, McGraw-Hill Higher Education, 2003, p.626.

$\overline{\text { Manuscript received: } 25.07 .2019}$ 
